\title{
KESERIUSAN PENGELOLAAN ADMINISTRASI MATERIIL DI INSTANSI PEMERINTAH
}

\author{
Idi Setyo Utomo ${ }^{1}$
}

\begin{abstract}
Article discusses one of the source or input needed by organization to achieve their goals, that is contribution. Contribution as country asset need to be organized. Because it is not simple to run the country asset or contribution. The country asset must be well organized so that the government effort on developing country asset must be done simultaneously and it becomes an integral part of national development.
\end{abstract}

Keywords: administration, government

ABSTRAK
Artikel membahas salah satu sumber daya atau input yang diperlukan organisasi untuk
mencapai tujuan yang telah ditetapkan, yaitu benda/fisik yang sering disebut juga dengan
materiil. Materiil sebagai kekayaan negara perlu diatur pengelolaannya secara bertanggung
jawab. Hal itu disebabkan pengelolaan terhadap barang milik negara/kekayaan negara atau
materiil itu tidaklah sederhana karena meliputi berbagai fungsi yang saling mengait. Karena
barang milik/kekayaan negara itu harus dikelola secara bertanggung jawab, upaya pemerintah
terhadap perbaikan pengelolaan barang milik/kekayaan negara itu perlu dilaksanakan secara
terus menerus dan merupakan bagian integral dari pembangunan nasional.
Kata kunci: administrasi, materiil, pemerintah

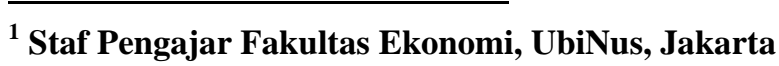




\section{PENDAHULUAN}

Dalam rangka kelancaran pelaksanaan kegiatan suatu organisasi untuk mencapai tujuan yang telah ditetapkan diperlukan adanya sumber daya atau input yang diperoleh dari lingkungan yang dapat dikelompokkan menjadi input sumber daya manusia, fisik, keuangan, dan informasi. Salah satu sumber daya atau input yang diperlukan oleh organisasi dapat berupa benda/fisik yang sering disebut juga dengan materiil. Dengan demikian, materiil merupakan salah satu sumber daya yang sangat penting dalam proses pencapaian tujuan organisasi baik organisasi swasta yang mengejar laba maupun organisasi nirlaba atau bahkan organisasi pemerintah. Dalam kaitan antara materiil dan suatu organisasi pemerintahan ini, R.H.Koeswandi mendefinisikan materiil sebagai "Barang-barang dari semua kekayaan negara yang merupakan satuan tertentu yang dapat dihitung, diukur, dan ditimbang.”

Setiap manajemen mengharapkan agar pengelolaan sumber daya dapat dilakukan secara efektif dan efisien dalam mencapai tujuan organisasi. Dari rumusan yang diutarakan oleh R.H. Koeswandi tersebut maka materiil sebagai kekayaan negara perlu diatur pengelolaannya secara bertanggung jawab. Hal itu disebabkan pengelolaan terhadap barang milik negara/kekayaan negara atau materiil itu tidaklah sederhana karena meliputi berbagai fungsi yang saling mengait. Karena barang milik/kekayaan negara ini harus dikelola secara bertanggung jawab, upaya pemerintah terhadap perbaikan pengelolaan barang milik/kekayaan negara ini perlu dilaksanakan secara terus menerus dan merupakan bagian integral dari pembangunan nasional.

Mengenai arti pentingnya usaha perbaikan dan penyempurnaan administrasi pemerintah dapat dilihat pada setiap awal tahun anggaran baru pemerintah selalu mengeluarkan Keputusan Presiden tentang Pelaksanaan Anggaran Pendapatan dan Belanja Negara yang beberapa pasalnya mengatur mengenai hal tersebut. Adalah merupakan kebiasaan yang baik bahwa pada setiap 15 Agustus Presiden RI selalu menyampaikan pidato kenegaraan di dalam sidang pleno Dewan Perwakilan Rakyat Republik Indonesia dan salah satu masalah pokok yang dikemukakan dalam pidato tersebut adalah mengenai rencana angaran pendapatan dan belanja negara tahun yang akan datang.

Sejalan dengan judul artikel ini, penulis ingin mengemukakan pengertian tentang Administrasi Materiil yang merupakan cabang dari Ilmu Administrasi sebagaimana diutarakan oleh R.H. Koeswandi, yaitu "Cabang Administrasi ini mempelajari segenap proses penyelenggaraan yang mengenai kebutuhan, penyediaan dan penggunaan alat, benda, tempat kerja, dan fasilitas lainnya dalam usaha bekerjasama manusia”. Dari pengertian di atas dapat dimengerti kalau dalam penerapannya, administrasi materiil di instansi pemerintah pun memerlukan tenaga dan pimpinan yang memahami tentang ilmu administrasi. Untuk pembahasan selanjutnya, dalam artikel ini penulis membatasi pelaksanaan administrasi materiil pada ruang lingkup pada Badan Penelitian dan Pengembangan Pertanian, Departemen Pertanian.

Badan Penelitian dan Pengembangan Pertanian Departemen Pertanian (selanjutnya disingkat dengan Badan Litbang Pertanian) dibentuk berdasarkan Keputusan Presiden RI No.45 Tahun 1974 yang pelaksanaannya diatur kemudian dengan Keputusan Menteri Pertanian No.190 Tahun 1975. Sejak berdirinya sampai sekarang, Badan Litbang Pertanian telah mengalami beberapa kali perubahan dan terakhir diatur dengan Keputusan Presiden No. 165 dan 177 Tahun 2001 serta Keputusan Menteri Pertanian No.01 dan No.99 Tahun 2001. Berdasarkan keputusan Menteri Pertanian tersebut Badan Litbang Pertanian mempunyai tugas Melaksanakan penelitian 
dan pengembangan di bidang pertanian. Dalam melaksanakan tugas tersebut Badan Litbang Pertanian menyelenggarakan fungsi sebagai berikut.

1. Perumusan kebijaksanaan penelitian dan pengembangan teknologi tinggi dan strategis di bidang pertanian.

2. Perumusan program kegiatan penelitian dan pengembangan teknologi tinggi dan strategis di bidang pertanian.

3. Pelaksanaan kegiatan penelitian dan pengembangan teknologi tinggi dan strategis di bidang pertanian.

4. Evaluasi pelaksanaan penelitian dan pengembangan teknologi tinggi dan strategis di bidang pertanian.

5. Pelaksanaan administrasi Badan.

Selanjutnya, berdasarkan Keputusan Menteri Pertanian No.01/Kpts/OT.210/ 1/2001 Tahun 2001 tentang Organisasi dan Tata Kerja Departemen Pertanian, Badan Litbang Pertanian terdiri atas berikut ini.

1. Sekretariat Badan

2. Pusat Penelitian dan Pengembangan Sosial Ekonomi Pertanian

3. Pusat Penelitian dan Pengembangan Tanaman Pangan

4. Pusat Penelitian dan Pengembangan Hortikultura

5. Pusat Penelitian dan Pengembangan Perkebunan

6. Pusat Penelitian dan Pengembangan Peternakan

7. Pusat Penelitian dan Pengembangan Tanah dan Agroklimat

Ketujuh unit kerja tersebut merupakan unit kerja eselon II/a yang berada di bawah dan bertanggung jawab kepada Kepala Badan Litbang Pertanian. Selain itu, berdasarkan Keputusan Menteri Pertanian No. 403 Tahun 2003 Badan Litbang juga membawahi Balai Besar Pengembangan Mekanisasi Pertanian, suatu unit kerja setingkat eselon II/b. Badan Litbang Pertanian juga memiliki 49 unit pelaksana teknis yang lokasinya menyebar di seluruh wilayah Indonesia. Dengan menyebarnya lokasi unit kerja tersebut maka keberadaan barang-barang milik negara yang berada di bawah kekuasaannya juga mengikuti keberadaan lokasi unit kerja yang bersangkutan. Sebagai unit kerja eselon I Badan Litbang Pertanian diharapkan dapat menangani pengelolaan barang-barang milik negara atau materiil yang dipergunakan, baik untuk pelaksanaan tugas rutin maupun tugas pembangunan.

Pengelolaan materiil atau barang-barang inventaris pada Badan Litbang Pertanian ini kegiatannya sehari-hari ditangani oleh Subbagian Perlengkapan yang mempunyai tugas melaksanakan pembinaan dan pengurusan Perlengkapan Badan Litbang Pertanian. Di samping adanya kewajiban bagi setiap instansi pemerintah termasuk Badan Litbang Pertanian untuk melaksanakan pengelolaan terhadap barang milik negara maka kepada setiap instansi pemerintah tersebut diharuskan pula untuk membuat laporan secara teratur dan berkala kepada instansi atasannya secara hierarkis.

Berdasarkan ketentuan tersebut maka kepada suatu instansi pemerintah dituntut adanya satu tanggung jawab yang baik dan benar terhadap materiil atau barang inventaris yang dikelolanya. Dalam rangka pelaksanaan pengelolaan barang-barang inventaris secara bertanggung jawab tersebut Badan Litbang Pertanian memerlukan tenaga terampil yang diharapkan dapat bekerja secara efisien, efektif, dan penuh pengabdian. Hal itu disebabkan Badan Litbang Pertanian memiliki 7 (tujuh) unit kerja eselon II serta unit di bawahnya yang tersebar di seluruh wilayah Indonesia, ditambah satu unit kerja setingkat eselon II/b. Unit kerja yang berada di daerah tersebut 
terdiri atas sejumlah Balai Penelitian berdasarkan komoditas (tanaman pangan, tanaman industri, hortikultura, dan peternakan) dan Balai Pengkajian Teknologi Pertanian, suatu balai dengan spesifikasi sesuai lokasi balai tersebut berada. Dengan demikian, barang milik negara yang harus ditangani oleh SubBagian Perlengkapan ini cukup beragam dan banyak jumlahnya serta tersebar penempatannya sesuai dengan lokasi unit kerja yang bersangkutan.

Idealnya, dengan pengelolaan materiil atau barang-barang inventaris secara baik dan bertanggung jawab maka diharapkan tercipta hal berikut.

1. Dapat diwujudkan adanya suatu tertib administrasi barang atau materiil.

2. Letak atau lokasi barang inventaris dapat diketahui secara pasti.

3. Dalam merencanakan pengadaan barang inventaris pada waktu yang akan datang didasarkan pada data yang pasti sehingga mengurangi pemborosan.

4. Barang-barang inventaris yang sudah tidak berfungsi atau barang tua/berlebih dan merupakan beban dalam pemeliharaannya, mudah diketahui untuk diproses penghapusannya.

5. Dapat digunakan sebagai bahan untuk menghitung atau menilai kekayaan negara atas barangbarang inventaris yang dimiliki.

6. Dalam memelihara barang inventaris dapat disusun dan diatur pembuatan jadwalnya.

7. Mempermudah pengawasan atas barang-barang inventaris.

Sebagai acuan dalam pengelolaan materiil ini, dasar hukum yang dipergunakan oleh Badan Litbang Pertanian sebagai berikut.

1. Undang-undang Perbendaharaan Indonesia (Indische Comptabiliteit Wets) Stbl.1925 No.448 terakhir diubah dengan Undang-undang No.9/1968, tentang Cara Pengurusan Pertanggungjawaban Keuangan Negara Republik Indonesia, dan Stbl. 1866 No.151 terakhir diubah dengan Stbl.1926 No.58 tentang pengurusan Administrasi Barang dan Pertanggungjawabannya.

2. Instrukdi Presiden RI No.3 Tahun 1971 tentang Inventarisasi Barang-barang Milik Negara atau kekayaan negara.

3. Keputusan Menteri Keuangan No.Kep-225/KMK/V/4/1971 tentang Pedoman Umum Pelaksanaan Inventarisasi Barang Milik/Kekayaan Negara.

4. Keputusan Menteri Keuangan No.470/KMK.01/1994 tentang Tata Cara Penghapusan dan Pemanfaatan Barang Milik/Kekayaan Negara.

5. Keputusan Menteri Pertanian No.660/Kpts/OT.220/8/96 tentang Pedoman Pelaksanaan Inventarisasi Barang Milik/Kekayaan Negara lingkup Departemen Pertanian.

Sebagai suatu organisasi Pemerintah, Badan Litbang Pertanian juga mengenal adanya hubungan antara unit kerja yang satu dengan unit kerja yang lain dalam jajaran Badan Litbang Pertanian yang disebut juga dengan mengadakan hubungan secara intern. Hubungan kerja itu dilakukan secara vertikal mau pun secara horisontal. Komunikasi/hubungan kerja vertikal merupakan bagian yang penting dalam suatu organisasi karena dalam hal ini akan terjadi penyampaian pesan/informasi timbal balik antara atasan dan bawahan atau sebaliknya. Salah satu wujud nyata bentuk hubungan ini dalam pelaksanaan inventarisasi barang milik/kekayaan negara adalah penyampaian laporan pengelolaan barang yang dimiliki unit pemilik barang secara teratur. Laporan pengelolaan barang inventaris dari unit kerja lingkup Badan Litbang Pertanian ini akan diolah oleh Subbagian Perlengkapan yang nantinya akan dilaporkan kepada Departemen Pertanian.

Selain hubungan kerja secara intern, Badan Litbang Pertanian juga melakukan hubungan kerja secara ekstern dengan instansi di luar Badan Litbang Pertanian, seperti Sekretariat Jenderal 
Departemen Pertanian, Dapartemen Keuangan, dan Badan Perencanaan Pembangunan Nasional mau pun instansi pemerintah lainnya serta lembaga swasta baik dalam mau pun luar negeri. Di samping adanya hubungan kerja intern dan ekstern tersebut, Badan Litbang Pertanian juga mengenal adanya hubungan kerja sama dengan lembaga internasional, khususnya lembaga yang bergerak di bidang penelitian dan pengembangan teknologi. Dari jalinan hubungan kerja sama tersebut Badan Litbang Pertanian memperoleh bantuan berbagai macam peralatan yang sangat membantu untuk kegiatan operasional organisasi maupun kegiatan penelitian dan pengembangan teknologi di bidang pertanian.

Selanjutnya, Subbagian Perlengkapan yang bertanggung jawab menangani pengelolaan materiil mempunyai tugas melaksanakan pembinaan dan pengurusan perlengkapan Badan Litbang Pertanian yang dalam melaksanakan tugas tersebut Subbagian Perlengkapan menyelenggarakan fungsi sebagai berikut.

1. Melakukan inventarisasi dan menyusun rencana kebutuhan perlengkapan.

2. Melakukan urusan pengadaan dan penyaluran perlengkapan.

3. Melakukan urusan penghapusan perlengkapan.

4. Menghimpun laporan inventarisasi, mengolah, dan menyiapkan laporan triwulanan serta laporan tahunan.

Subbagian Perlengkapan itu dipimpin oleh seorang kepala dan memiliki 4 (empat) orang staf pelaksana pengelolaan inventarisasi barang milik.kekayaan negara. Keempat staf Subbagian Perlengkapan tersebut mendapat tugas menangani unit kerja baik yang mengelola anggaran rutin mau pun anggaran pembangunan dengan pembagian tugas sebagai berikut.

1. Seorang petugas menangani lingkup Sekretariat Badan, dan Puslitbang Tanah dan Agroklimat termasuk Balai yang ada di bawahnya, dan Asosiasi Penelitian Perkebunan Indonesia.

2. Seorang petugas menangani lingkup Puslitbang Sosial Ekonomi Pertanian termasuk Balai yang ada di bawahnya.

3. Seorang petugas menangani lingkup Puslitbang Tanaman Pengan termasuk Balai yang ada di bawahnya, Puslitbang Tanaman Industri termasuk Balai yang ada di bawahnya, dan Balai Besar Pengembangan Mekanisasi Pertanian.

4. Seorang petugas menangani lingkup Puslitbang Hortikultura termasuk Balai yang ada di bawahnya dan Puslitbang Peternakan termasuk Balai yang ada di bawahnya.

Pada prinsipnya, rincian tugas tersebut meliputi sebagai berikut.

1. Melakukan penyiapan bahan penyusunan rencana pengadaan barang lingkup Badan Litbang Pertanian.

2. Melakukan inventarisasi barang milik/kekayaan negara lingkup Badan Litbang Pertanian.

3. Melakukan penyiapan bahan penghapusan barang milik/kekayaan negara lingkup Badan Litbang Pertanian.

4. Melakukan urusan tata usaha barang milik/kekayaan negara lingkup Badan Litbang pertanian.

Dari data lima tahun terakhir kekayaan Badan Litbang Pertanian selalu menunjukkan pertambahan setiap tahunnya seperti ditampilkan dalam tabel 1 di bawah ini. 
Tabel 1 Nilai Kekayaan Badan Litbang Pertanian dari 1997 - 2002

\begin{tabular}{lcc}
\hline \multicolumn{1}{c}{ Tahun Anggaran } & Nilai Kekayaan & Kenaikan \\
\hline $1997 / 1998$ & Rp 188.660.229,-- & $9 \%$ \\
$1998 / 1999$ & Rp 197.725.012,-- & $4,82 \%$ \\
$1999 / 2000$ & Rp 216.429,268,14 & $9,46 \%$ \\
2001 & Rp 242.848.157,69 & $3,48 \%$ \\
2002 & Rp 250.049.792,61 & $2,94 \%$ \\
\hline
\end{tabular}

Sumber: Subbagian Perlengkapan Badan Litbang Pertanian

Dari tabel di atas diketahui bahwa pengggunaan tahun anggaran dalam sistem pembukuan adminisrisasi materiil mengalami perubahan. Sebelum 2001 tanggal pembukuan dilakukan mulai dari 1 April sampai dengan 31 Maret tahun berikutnya sedangkan mulai 2001 tanggal pembukuan dimulai menggunakan tahun kalender, yaitu mulai 1 Januari sampai dengan 31 Desember tahun yang bersangkutan. Pengadaan barang milik/kekayaan negara selama lima tahun terakhir sejak 1997/98 selalu mengalami peningkatan dalam nilai rupiah. Pada 1997/98 nilai kekayaan Badan Litbang Pertanian adalah $R p$ 188.660.229.000,-. Kemudian pada 1998/99 naik sebesar 4,82\% menjadi $R p$ 197.725.012.930,- pada 1999/00 naik 9,46\% menjadi $R p$ 216.429.268.140; pada 2001 naik 3,48\% menjadi $R p$ 242.848.157.690,- dan pada 2002 mengalami kenaikan 2,94\% menjadi $R p$ 250.049.792.610,-.

Inventarisasi yang dilakukan oleh setiap UPB itu secara berkala dilaporkan kepada Kepala Badan Litbang Pertanian selaku Penguasa Barang Inventaris (PBI) yang penanganannya dilaksanakan oleh Subbagian Perlengkapan seperti dijelaskan sebelumnya.. Setelah laporan itu diolah kemudian akan dilaporkan kepada Departemen Pertanian selaku Kuasa Pembina Barang Inventaris (Kuasa Pebin). Dari himpunan laporan seluruh UPB tersebut maka pada Subbagian Perlengkapan tersimpan dokumen inventarisasi barang/materiil seperti berikut.

1. Kartu Inventaris Barang

2. Laporan Rincian dari UPB

3. Laporan Rekapitulasi dari UPB

4. Laporan Rekapitulasi dari Badan Litbang (Penguasan Barang Inventaris/PBI) kepada Departemen Pertanian (Pembina Barang Inventaris/Pebin).

Pengadaan barang baik melalui anggaran rutin maupun anggaran pembangunan pelaksanaannya diserahkan kepada masing-masing Unit Pemakai Barang berdasarkan perencanaan kebutuhan yang telah disusun sebelumnya. Hasil pelaksanaan pengadaan tersebut setelah dimasukkan ke dalam buku induk barang dan buku pembantu sesuai jenis barangnya kemudian dilaporkan kepada Sekretaris Badan Litbang Pertanian yang selanjutnya diserahkan kepada Subbagian Perlengkapan untuk diproses lebih lanjut sesuai ketentuan peraturan yang berlaku. Menurut ketentuan yang berlaku, barang milik/kekayaan negara yang berada dalam penguasaan Badan Litbang Pertanian dikelompokkan menjadi 4 (empat) golongan besar, yaitu barang tidak bergerak, barang bergerak, hewan/ternak, dan tanaman.

Setiap Unit Pemakai Barang diwajibkan membuat laporan mutasi barang triwulanan dan laporan tahunan/rekapitulasi yang pembuatannya berpedoman pada Surat Keputusan Menteri Keuangan Nomor KEP 225/MK/V/1971, yaitu menggunakan buku dan Kartu Inventaris Barang (KIB). Mengingat akan banyaknya barang serta jenis barang yang dimiliki maka pelaporan dengan 
sistem KIB itu diperkirakan akan terdapat ribuan KIB. Oleh karena itu, untuk sementara ini jenis barang yang dimasukkan datanya menggunakan KIB ini dilakukan secara bertahap dan untuk tahap sekarang ini sebagai berikut.

1. Tanah

2. Gedung Kantor

3. Rumah Tinggal

4. Alat Pengangkutan

5. Alat-alat Besar

6. Mesin Kantor dan

7. Monumen

Selanjutnya, UPB yang mengelola anggaran rutin ini disebut dengan UPB rutin dan yang mengelola anggaran pembangunan disebut dengan UPB proyek. Jumlah atau keberadaan UPB rutin maupun UPB proyek itu selalu berubah setiap tahun berdasarkan unit kerja atau pun proyek yang dikelola oleh Badan Litbang Pertanian. Untuk tahun anggaran 1999/2000 misalnya, di Badan Litbang Pertanian terdapat 120 UPB yang terdiri atas UPB rutin 42 buah dan UPB proyek 78 buah. Pada tahun anggaran 2001 terdapat 107 UPB yang terdiri atas UPB rutin 41 buah dan UPB proyek 66 buah. Untuk tahun anggaran 2002, di Badan Litbang Pertanian terdapat sebanyak 134 UPB yang terdiri atas 57 UPB rutin dan 77 UPB proyek.

\section{PEMBAHASAN}

Dari tahun ke tahun berdasarkan laporan inventarisasi yang disampaikan oleh UPB kepada Sekretariat Badan Litbang Pertanian dapat diketahui bahwa jumlah barang/perlengkapan yang dimiliki oleh instansi itu selalu bertambah (Tabel 1 di bagian depan). Pertambahan kekayaan Badan Litbang Pertanian itu diketahui dari laporan yang diterima dari setiap UPB. Sesuai ketentuan yang berlaku maka kepada setiap UPB diwajibkan menyusun dan menyampaikan laporan mutasi barang triwulanan maupun laporan tahunan kepada Sekretariat Badan Litbang Pertanian. Walaupun laporan dari UPB adakalanya tidak diterima secara lengkap namun pertambahan kekayaan itu terjadi setiap tahun. Berikut ini penulis menyajikan data laporan mutasi barang triwulanan (LMBT) dan laporan tahunan (LT) untuk periode tahun anggaran 1999/2000, tahun anggaran 2001, dan tahun anggaran 2002 seperti tertuang dalam Tabel 2 di bawah ini.

Tabel 2 Unit Pemakai Barang (UPB) yang Mengirimkan Laporan Mutasi Barang Triwulanan dan Laporan Tahun Lingkup Badan Litbang Pertanian

\begin{tabular}{lcccccc}
\hline Th.Anggaran & $\begin{array}{l}\text { Jumlah } \\
\text { UPB }\end{array}$ & LMBT I & LMBT II & LMBT III & LMBT IV & LT \\
\hline $1999 / 2000$ & 120 & $\begin{array}{c}64 \\
(53,3 \%)\end{array}$ & $\begin{array}{c}58 \\
(48,3 \%)\end{array}$ & $\begin{array}{c}76 \\
(63,3 \%)\end{array}$ & $\begin{array}{c}79 \\
(65,8 \%)\end{array}$ & $101(84 \%)$ \\
\hline 2001 & 107 & $\begin{array}{c}51 \\
(47,6 \%)\end{array}$ & $6964,4 \%)$ & $\begin{array}{c}73 \\
(68,2 \%)\end{array}$ & $\begin{array}{c}62 \\
(67,2 \%)\end{array}$ & $8276,6 \%)$ \\
\hline 2002 & 134 & $\begin{array}{c}50 \\
(37,3 \%)\end{array}$ & $5843,2 \%)$ & $\begin{array}{c}60 \\
(44,7 \%)\end{array}$ & $\begin{array}{c}57 \\
(42,5 \%)\end{array}$ & $\begin{array}{c}94 \\
(70,1 \%)\end{array}$ \\
\hline
\end{tabular}

Sumber: Subbagian Perlengkapan Badan Litbang Pertanian 
Dari tabel di atas dapat diketahui bahwa tidak semua UPB membuat dan mengirimkan laporan baik Laporan Mutasi Barang Triwulanan maupun Laporan Tahunan. Padahal, pembuatan dan penyampaian laporan merupakan kewajiban yang harus dilakukan setiap UPB seseuai ketentuan yang berlaku. Untuk tahun anggaran 1999/2000 misalnya, dari 120 UPB yang ada masing-masing hanya 53,3\% yang mengirimkan LMBT I, 48,3 \% mengirimkan LMBT II, 63,3\% mengirimkan LMBT III, dan 65,8\% mengirimkan LMBT IV sedangkan UPB yang menyampaikan Laporan Tahunan sebanyak 84\%.

Pada tahun anggaran 2001, jumlah UPB lingkup Badan Litbang Pertanian mengalami penurunan, yaitu hanya 107 buah (UPB rutin dan UPB Pembangunan). Dari jumlah tersebut UPB yang mengirimkan LMBT I sebesar 47,6\%, LMBT II 64,4\%, LMBT III 68,2\%, dan LMBT IV 67,2\% sedangkan UPB yang mengirimkan Laporan Tahunan sebesar 76,6\%. Pada tahun anggaran 2002 jumlah UPB lingkup Badan Litbang Pertanian berubah lagi dan bertambah menjadi 134 buah. Dari jumlah tersebut yang mengirimkan LMBT I hanya 37,3\%, LMBT II 43,2\%, LMBT III 44,7\% dan LMBT IV 42,5\% sedangkan UPB yang mengirimkan Laporan Tahunan sebesar 70,1\%.

Selama periode 3 tahun tersebut terlihat bahwa Laporan Tahunanan yang disampaikan oleh UPB selalu mengalami penurunan. Tahun anggaran 1999/2000 UPB yang meyampaikan Laporan Tahunan sebesar 84\%, tahun anggaran 2001 menurun menjadi 76,6\%, dan tahun anggaran 2002 menurun lagi menjadi hanya 70,1\%. Keadaan itu sungguh sangat memprihatinkan karena berarti untuk tahun anggaran 2002 saja sebanyak 29,9\% kekayaan Badan Litbang Pertanian yang tidak dilaporkan. Suatu jumlah cukup besar kalau dinilai dengan mata uang rupiah, padahal peroleh barang/perlengkapan tersebut bersumber sebagian besar dari Anggaran Pendapatan dan Belanja Negara. Menyimak laporan tersebut tersirat kurang adanya keseriusan terhadap pengelolaan materiil yang dikuasai oleh Badan Litbang Pertanian ini.

Dengan dasar fungsi inventarisasi di atas maka penulis mengasumsikan bahwa inventarisasi sangat besar peranannya bagi instansi pemerintah, dalam hal ini Badan Litbang Pertanian. Apabila pengelolaan kekayaan negara itu tidak dilakukan secara bertanggung jawab dikhawatirkan suatu saat akan menimbulkan hal yang tidak diinginkan terhadap kekayaan negara tersebut (misalnya hilang tanpa dapat ditelusuri jejaknya). Berarti akan mengakibatkan kerugian bagi negara yang kalau dibiarkan akan semakin membesar nilainya.

Mengingat banyaknya unit kerja yang dimiliki oleh Badan Litbang maka keberadaan 4 orang tenaga staf Subbagian Perlengkapan terasa sangat kurang memadai. Kekurangan tenaga pengelola itu sebenarnya sudah dirasakan cukup lama tetapi karena adanya kebijaksanaan pemerintah secara nasional yang membatasi penerimaan pegawai baru (zero growth) maka tambahan tenaga yang diharapkan sangat sulit terpenuhi. Idealnya jumlah tenaga pengelola maeriil ini adalah 7 (tujuh) orang dengan pertimbangan setiap orang menangani satu eselon II berikut unit pelaksana teknis yang berada di bawahnya. Dengan demikian, saat ini masih diperlukan tambahan 3 (tiga) orang staf lagi di Subbagian Perlengkapan ini. Keadaan tenaga pada Subbagian Perlengkapan ini juga dialami oleh Unit Pemakai Barang yang berada di daerah, terlebih daerah terpencil di luar pulau Jawa. Kurangnya tenaga pengelola materiil itu berakibat pada pelaksanaan fungsi administrasi materiil dan penyusunan laporan yang tidak tepat waktu. Bahkan, terdapat sejumlah Unit Pemakai Barang yang tidak dapat menyampaikan laporan mutasi barang triwulanan maupun laporan tahunan. 


\section{PENUTUP}

\section{Simpulan}

Dari uraian di atas dapat disimak bahwa pengadaan dan perolehan barang inventaris/milik negara ini bersumber dari anggaran pendapatan dan belanja negara yang berarti semuanya itu merupakan uang rakyat harus dipertanggungjawabkan secara baik dan benar. Dalam hal ini, sangat diperlukan adanya kesungguhan dalam mewujudkan good governance di bidang pengelolaan materiil milik instansi pemerintah, khususnya Badan Litbang Pertanian. Oleh karena itu, berdasarkan pengalaman di atas, penulis menyarankan agar penambahan tenaga pengelola inventaris di Badan Litbang Pertanian ini perlu dilakukan secepatnya untuk mengelola kekayaan milik negara yang nilainya cukup besar dan selalu bertambah setiap tahun. Meskipun ada kebijakan "zero growth" di bidang kepegawaian, penambahan tenaga pengelola barang inventaris disarankan untuk dilakukan dengan mengajukan permintaan khusus kepada instansi yang berwewenang.

Mengenai penyampaian laporan baik Laporan Mutasi Barang Triwulanan maupun Laporan Tahunan yang tidak dapat dipenuhi seseuai ketentuan yang berlaku, disarankan perlunya keseriusan instansi yang bersangkutan untuk mewujudkan tertib administrasi materiil sehingga cita-cita good governance tidak hanya merupakan wacana. Dari kelemahan pengelolaan materiil itulah dapat muncul bibit korupsi, kolusi, dan nepotisme (KKN) yang sangat meresahkan dan ingin diberantas bersama.

\section{DAFTAR PUSTAKA}

Instruksi Presiden RI No.3 Tahun 1971 tentang Inventrisasi Barang-barang Milik Negara/Kekayaan Negara.

Keputusan Presiden RI No.44 Tahun 1974 tentang Pokok Organisasi Departemen.

Keputusan Presiden RI No.45 Tahun 1974 tentang Susunan Organisasi Departemen.

Keputusan Presiden No. 165 dan 177 Tahun 2001 tentang Susunan Organisasi Departemen.

Keputusan Menteri Keuangan No.KEP 225/MK/V/4/1971 tentang Pedoman Pelaksanaan Inventarisasi Barang-barang Milik Negara/Kekayaan Negara.

Keputusan Menteri Pertanian No. 01/Kpts/OT.210/1/2001 Tahun 2001 tentang Organisasi dan Tata Kerja Departemen Pertanian.

Koeswandi, R.H. Administrasi Materieel. Jakarta.

M. Hanafi, Mamduh. 1997. Manajemen. Cetakan pertama. Yogyakarta: Unit Penerbit dan Percetakan Akademi Manajemen Perusahaan YKPN. 